\title{
Temporary organizing and permanent contexts
}

Current Sociology Monograph 2020, Vol. 68(4) 480-498 (C) The Author(s) 2020

Article reuse guidelines: sagepub.com/journals-permissions DOI: 10.1 I77/00। I392120907629 journals.sagepub.com/home/csi

@SAGE

\section{Jörg Sydow}

Freie Universität Berlin, Germany

\section{Arnold Windeler (iD)}

Technische Universität Berlin, Germany

\begin{abstract}
Temporary organizing in general and project-based organizing in particular are to be understood only in relation to more permanent contexts such as organizations, inter-organizational networks, industries/fields and society. In view of the ability of organizations to balance permanency and temporariness, they are unlikely to disappear due to temporary organizing. Rather, they will continue to change their form recurrently and, thereby, remain as an essential building block of our more fluid societies today. Using a practice-based perspective informed by structuration theory and critically reviewing empirical studies of project-based organizations and inter-organizational project networks, this article provides a deeper understanding of the complex interplay between the temporary and the permanent.
\end{abstract}

\section{Keywords}

Anthony Giddens, bureaucracies, organizations, practice-based organizations, practice theory, (project) networks, temporary organizing

\section{Introduction}

Modern societies have aptly been described by Max Weber (1968 [1922]) and, many decades later, by Charles Perrow (1991), as 'societies of organizations'. Today, the question arises: Do the increasingly common forms of temporary organizing (Lundin et al., 2015) question the prominent role of organizations, or do these very forms rely heavily on the more permanent structures that are often provided by organizations?

\section{Corresponding author:}

Arnold Windeler, Department of Sociology, Technische Universität Berlin, Fraunhoferstraße 33-36, FH 9-I, Berlin, 10587, Germany.

Email: arnold.windeler@tu-berlin.de 
Project-based forms of organizing probably date back to antiquity (Ekstedt et al., 1999; Packendorff, 1995). In some industries, like filmmaking (DeFillippi and Arthur, 1998) or construction (e.g. Eccles, 1981), projects have a very long tradition indeed. Today, a myriad of other industries are also utilizing this organizational form. Among them are advertising (Grabher, 2004), biotechnology (Powell et al., 1996) and content production for television (Windeler and Sydow, 2001; for an extended list of industries see Bakker, 2010: 466-467). But will the spread of forms of temporary organizing (cf. Bakker et al., 2016: 1706-1707), which significantly affects wider societal issues such as economic inequality or social cohesion, lead to a society without organizations, or at least to one in which organizations play a far less prominent role than today? For decades, organizations - following Max Weber - were considered to be essential building blocks of modern societies, as they drive the rationalization of the world, inscribing into the world a rationalized order based, in particular, on bureaucratic organizations with their stable, regular and formalized character. Will this diagnosis lose validity in view of the spread of temporary forms of organizing?

In this article, we argue that organizations - with their institutionalized structures and practices - will continue to exist along with the spreading forms of temporary organizing in general and project-based organizing in particular. Indeed, organizations will transform and thereby contribute to the fundamental change towards a more fluid society (Bauman, 2007), which, however, will continue to be based on the stability of an organization's form of coordination. Thereby, organizations are not only confronted with or even threatened by this trend towards intentional temporariness; they also actively shape this development, not least by starting projects and developing project-based forms of organizing. Even more importantly, beyond all the talk about the rise of temporary coordination principles in present societies, it is necessary not to lose sight of permanence as a vital precondition for temporary organizing (Farjoun, 2010). Focusing on the relationship between the temporary and the permanent opens the way to a better understanding of the more permanent contexts of organizing, of how they impact temporary forms of coordination and their consequences for society as a whole.

In what follows, we first clarify what is meant by organization and organizing in relation to the interplay of the temporary and the permanent in temporary organizing. Then, we briefly outline a practice-based perspective of analysis that builds on structuration theory (Giddens, 1984). Discussing exemplary empirical studies, we illustrate the interplay of the temporary and the permanent in two different, relatively stable settings: first, within organizations and second, within inter-organizational networks. We conclude with a discussion of the role in society of temporary organizing and its necessary counterpart, permanency, from a practice-based perspective.

\section{Organization, organizing and temporary organizing: The interplay of the permanent and the temporary from a practice-based perspective}

In the tradition of Max Weber (1968 [1922]), organizations were conceived as bureaucracies, characterized by codified rules, hierarchical order, enduring routines, procedures or programmes (e.g. Blau and Scott, 2003 [1962]). Since such organizations are usually 
established without an ex-ante termination in mind, they are characterized as being of a more or less permanent nature. Though for Weber the enduring features of bureaucratic organizations significantly shape organizational life, he was obviously quite conscious of the necessity to continuously organize and reorganize this type of social system. Thus, for example, he emphasizes the continuous tasks of performing and reinforcing the bureaucratic order.

In this regard, the more recent literature on organizing often claims the opposite to Weber's view of organization. For example, Karl Weick (2009: 7) writes, 'When we talk about organizing rather than organization, we acknowledge impermanence.' Thus, Weick puts the impermanence of organizations centre stage, characterizes organizations as 'organized impermanence' and focuses mainly on the fabrication of permanence out of impermanence. Consequently, this author concentrates on the ways in which actors talk 'situations, organizations, and environments . . . into existence' (Weick et al., 2005: 409) and enact orders in the flux of events. Though for Weick, sense-making is social and systemic (Weick et al., 2005: 412) as it 'might include previous discussions' (p. 412) with others as well as references to established organizational or professional systems, for him, the more stable orders emerge as 'texts, conversations, and interdependent activity' (Weick, 2009: 4). This view very much anticipated the more recent debate about organizational becoming (Langley et al., 2013), which, together with the respective process philosophies (Helin et al., 2014), has led to the promotion of a strong process view on organizations and organizing.

Based on these opposing characterizations of organizations, one can state provisionally that there is a fundamental tension between permanence and impermanence in the production and reproduction of organizations or processes of organizing more broadly. Permanent orders as well as ongoing temporary activities and structures are both characteristic of any organization, yet to different degrees. Three obvious consequences follow. First, both analytical perspectives, the permanence as well as the impermanence framework, are generally applicable in the context of organizations and organizing. However, the importance of one or the other perspective may vary with the questions asked, the problems solved, and the organizations observed. Second, the basic tension between the temporary and the permanent is also intertwined in 'temporary systems' (Goodman and Goodman, 1976), understood as settings with an institutionalized ex-ante termination of either the social systems or system membership, no matter whether this membership concerns individuals (as in the case of projects) or organizations (as in the case of interorganizational projects). Third, the focus on organizing activities, including in temporary systems, does not question per se the importance of enduring systemic conditions provided by organizations. It does not justify at all talking about the dissolution or even disappearance of organizations - either in absolute numbers or in societal importance. However, answering the respective questions is not that simple, because an intensified use of temporary organizing in general and projects in particular does indeed challenge organizations as we know them.

Let us take a closer look at temporary organizations. Rolf A Lundin and Anders Söderholm (1995) deliver the most prominent definition via the so-called 4T-framework of time, task, team and transition. Thereby, in short, time relates to the intended, ex-ante termination of the temporary organization; task refers to the uniqueness or repetitiveness 
of tasks to be accomplished in the timeframe set; team indicates groups that are intentionally formed around the task or around some aspect of it; and transition signifies the change achieved through the temporary organization. René M Bakker (2010: 479) later replaced the transition item of the Lundin and Söderholm framework with the context item, which focuses 'on the linkages between the temporary organizational venture and its enduring environment' (see also Engwall, 2003). The relevance of contexts is obvious, but should not necessarily replace the idea that temporary organizations are set up to perform a transition of some kind (Jacobsson et al., 2013). What is more important, however, is to understand the constitution of the 4Ts that plays out not only on the level of the single project but also as embedded in multiple contexts, from the organization to the society.

While Bakker et al. (2016: 1704, emphasis added) only recently stated that 'the notion of temporary organizing captures the activities and practices associated with collectives of inter-dependent actors who pursue ex-ante agreed upon tasks within a predetermined time frame', the investigation of the interplay between the temporary and the permanent has a longer tradition in research on project-based organizing (e.g. Sahlin-Andersson and Söderholm, 2002). Disentangling projects and organization opens the space for a clear conceptual understanding of the temporary and the permanent and sharpens awareness of the fact that temporary systems depend more on the permanent contexts - like organizations, inter-organizational networks, fields or societies - in which they are embedded. In consequence, any explanation of temporary systems should consider such multi-level embeddedness, interdependencies and the interplay of contexts to show how the temporary and the more permanent interact in order to understand what temporary organizing means for organizations and societies.

To improve our understanding, we propose a practice-based perspective on organization and organizing that is informed by structuration theory (Giddens, 1984), a perspective that has received some prominence in management and organization research during the last decades (Pozzebon, 2004; Sydow and Windeler, 1998; Windeler and Sydow, 2001; see for recent reviews Hond et al., 2012; Pozzebon, 2013; Whittington, 2010). Structuration theory is not only deeply processual, highlighting not only the interplay of action and structure as a duality; it similarly emphasizes the role of social systems, like projects or organizations, and their structural properties in social constitution (Windeler, 2001, 2006). This allows us to adopt a practice-based perspective that speaks to the relation of the temporary and the permanent and - in contrast to a strong process view - sees social processes and actors' activities and relations as being conditioned and coordinated by social systems on different levels of analysis and with different extensions in time-space.

Social systems, including projects as well as organizations, are relevant for the mutually interrelated social fabrication of permanence and impermanence. Knowledgeable actors within such systems reflexively enact structures of a focal social system and of relevant others as rule-resource sets, recursively in time-space (Giddens, 1984: 29), and apply or perform these 'in the enactment/reproduction of social practices' (Giddens, 1984: 21). That means that they draw on the social systems' rules and resources envisioned in action and use their understanding and knowledge of the situational context and its embeddedness in their activities. The reflexive and recursive use of structures 
- for instance, the use of an organization's sets of rules and resources when organizing a project - allows actors to signify and evaluate what is going on in the system and how to have an impact on the system. This means that a system's social practices enable agents to act in a knowledgeable way in the respective context - not least by interrelating different relevant social systems (like projects, organizations and society) in their project activities in time-space. The interrelated social fabrication of permanency and impermanency across different social systems and their structures is therefore deeply involved in social constitution.

If organizations install projects internally, they are the ones who, with a high degree of reflexivity (Giddens, 1990: 302), define the timeframes, tasks, teams, the envisioned transitions and the project contexts; they do this in the context of overall conditions regarding how, for instance, to allocate the necessary resources, evaluate project activities or constitute project boundaries (Windeler, 2018: 91-92). This means that managers often develop a rather focused knowledge and enact a set of practices regarding how to coordinate and regulate project activities in the organization's context by observing, evaluating and experimenting with project activities. Project participants also reflexively use their understanding of projects (as well as of contexts like organizations) in their project-related activities. Projects and their relevant organizational contexts are thus recursively constituted in time-space. This includes the fact that project participants do not need to develop the full range of structures from scratch, but are able to refer to and re-specify the ones they can enact from different contexts.

In a rather similar way, this is true for temporary endeavours in inter-organizational networks and fields - two other empirically highly important, more permanent contexts of today's projects. Inter-organizational networks are made up of repeatedly collaborating organizations. Organizational fields, by contrast, also include organizations that are relevant for (inter-) organizational interaction but do not necessarily collaborate. When the collaboration in inter-organizational networks is project-based, such networks may well be marked as 'project networks' (Windeler and Sydow, 2001). When an organizational field is dominated by project-based organizing, a 'project ecology' (Grabher, 2004) may arise.

Finally, projects, organizations, inter-organizational networks, fields or industries embed themselves (and are embedded) in societies (or societal totalities like the European Union). Societies influence actors' social interactions and relationships in particular via 'a specifiable overall "clustering of institutions" (Giddens, 1984: 164). National (or transnational) understandings of legitimized agency, activities and relationships allow for the recurrent, systemically re-specified binding and coordination of activities and the building of a social order with a significant degree of permanence in time-space, which, in turn, shape societal conditions.

This practice-based, moderate rather than strong process perspective that makes use of structuration theory follows a tall rather than flat ontology (Seidl and Whittington, 2014). Thereby, it asks for multi-level analyses of mutually interrelated social systems like societies, organizations and projects via the social practices agents produce and reproduce in time-space. What is more, such a perspective not only enables us to overcome the divide between structure and agency/process, but also to tackle the aforementioned puzzle 
between permanence and impermanence more dialectically. Thus, our practice-based perspective looks beyond the provisions of Lundin and Söderholm (1995) or Bakker et al. (2016), as it not only focuses on time, tasks, teams, transition and context separately but, in their interplay across different yet interrelated contexts, on multiple levels of analysis. What is more, this perspective highlights the role of social practices and how, over time and influenced not only by the experienced past but also the prospective future (Emirbayer and Mische, 1998), they are enacted, produced and reproduced by knowledgeable agents referring to the structures of different systems; thereby reproducing or transforming their very structures.

The proposed practice-based perspective informed by structuration theory does not only refer to the 'linkages between the temporary organizational venture and its enduring environments' (Bakker, 2010: 479), nor does it set activities and practices over structure as the strong process view is inclined to do. Rather, structuration theory provides a framework allowing the interplay between the temporary and the permanent to be analysed as a duality between action and structure (Farjoun, 2010). Since the social importance of structures is produced and reproduced by knowledgeable agents in recurrent activities, the permanence of a social setting cannot simply be equated with structure, nor, as to be found in the project management literature (e.g. Lundin and Söderholm, 1995), can the temporary be equated with action. What is more, 'project-based organizations' (Hobday, 2000; Lundin et al., 2015: 36-48) or 'project networks' (Windeler and Sydow, 2001) in industries like film production, consulting or construction should be considered as providing more than temporary settings in which individual and/or organizational agents are embedded and act. By reflexively picking up practices characteristic of the particular social system (and other social systems) and recursively referring to the system's rules and resources in their situational activities, actors typically actualize and re-specify sets of rules and resources of different social systems (e.g. of an organization, an inter-organizational network and a field) in their situated activities. This allows social actors to reflexively monitor, rationalize and motivate not only their own activities, but also the activities of others as well as the events they envision in relation to what is going on in relevant contexts. And by reflexively actualizing sets of rules and resources (of the project, the organization or other contexts) in their (project) practices, they (re-)produce them as well as the interplay between temporary organizations and their relevant, more permanent contexts. ${ }^{1}$

In sum, social orders, structures and actions with respect to time, tasks, teams, transition and context are seen as the medium and result of the activities of knowledgeable actors, who within or outside organizations recursively and reflexively enact social practices. Thereby - together with others - they continuously constitute such orders, structures and activities in time-space on different levels of analysis. In contexts of temporary organizing, the project level (temporary system) as well as the levels of organization, network and field are most important (as with more permanent systems). This understanding of multi-level social constitution allows us to overcome the dualism in favour of the duality between organization and organizing as well as between the permanent and the temporary. In consequence, this allows for an in-depth, processual and dialectical analysis of the interplay of temporary organizing with organizations or any other more permanent context in a theoretically informed way. ${ }^{2}$ 


\section{Temporary organizing in organizations and inter- organizational networks: Empirical evidence}

In the following, we will focus on temporary organizing in two differently organized contexts. The first context is project-based organizations or PBOs as a type of organization that combines temporary with permanent forms of coordination in a rather specific way but, in the end, relies on hierarchical authority. The second context is project networks, or PNWs, that coordinate projects with reference to a network governance. In both cases, we use several empirical studies that promise to address the 'temporary-permanent dilemma' (Sahlin-Andersson and Söderholm, 2002) and have been published in leading management journals. Most of them adopt a practice-based approach and all of them consider more than one level of analysis and use, at least additionally, qualitative methods, which promise to contribute to a better understanding of the temporary and the permanent from a process-oriented or even practice-based perspective. In these respects, the review is highly selective and does not aim to be representative of research on temporary organizations.

\section{Temporary organizing in (project-based) organizations}

For a long time, research about projects - the perhaps most prominent form of temporary organization - has mainly investigated these temporary systems within organizations that are usually intended to last. Their importance for (organizational) projects is obvious, as organizations not only define the 4T-framework of the project by selecting the project issue, the team members, the timeframe and the transition notified. In addition, organizations qualify how the project and project activities are evaluated, resources allocated, the project positioned (inside the organization as well as in the series of projects performed and foreseen) and the boundaries constituted (Windeler, 2001: 248-265; 2018: 90-96). Furthermore, from time to time, project members refer to and even intentionally re-specify the organization's sets of rules and resources in their activities as the organization's conditions, as they may or may not fit the requirements of the projects they lead or work for. Project members thus, actively and recursively, actualize the organization's conditions. This means that the organization's conditions not only restrict the project activities, but also enable them.

Even in the extreme case of a PBO, in which value is overwhelmingly and sometimes exclusively created with the help of projects, the organizational character of this form remains important (Hobday, 2000; Lundin et al., 2015: 36-48). Even if the organization as a permanent system is reduced to the top management team and some top management-supporting staff, this rather rudimentary but permanent hierarchy may suffice for a general constructor, a film production or consulting firm to coordinate activities within single projects or across a portfolio of projects, for instance by providing staff, implementing organizational rules, and supporting cross-project learning (Grabher, 2004).

In his seminal study, Mike Hobday (2000) not only clarifies our understanding of PBOs, but also looks at the development and production of complex industrial products and systems (CoPS). In this study, he compares two projects of similar value, duration, technology and customers in the two distinct business units of one German-owned firm 
that develops and produces advanced, high-cost scientific, industrial and medical equipment. What allows the comparison is the fact that one business unit manages projects as a PBO, while the other prefers a functional matrix organization. Hobday (2000: 871) concludes from his study that the $\mathrm{PBO}$ is:

... an intrinsically innovative form as it creates and recreates new organisational structures around the demands of each CoPS project and each major customer. The PBO is able to cope with emerging properties in production and respond flexibly to changing client needs. It is also effective at integrating different types of knowledge and skill and coping with the project risks and uncertainties common in CoPS projects. However, the PBO is inherently weak where the matrix organisation is strong: in performing routine tasks, achieving economies of scale, coordinating cross-project resources, facilitating company-wide technical development, and promoting organisation-wide learning. The PBO can also work against the wider interests of corporate strategy and business coordination.

However, as Hobday (2000), who does not make use of a process, not to mention a practice theory, shows, the weaknesses of the PBO can be overcome at least partially with the help of the routine-enhancing and project-tracking structures of the organization, i.e. the permanent system. With their help, too, project-centred activities, focused on the problem or task at hand at the expense of the efficiency and effectiveness of the entire organization, can be avoided.

Andrea Prencipe and Fredrik Tell (2001: 1380) also studied the development and manufacturing of CoPS when they explored the 'learning landscape' of PBOs, defined 'as the mix of project-to-project learning mechanisms adopted and implemented'. In all six PBOs, situated in the software, aerospace, defence, flight simulation and power generation industries, the authors unsurprisingly discovered that individual-level learning processes and practices are by and large similar. The PBOs, however, differ on the group/ project and, in particular, on the organizational level. Examples of knowledge articulation on the organizational level are the creation of professional networks and project manager camps, as well as the intensification of inter-project correspondence and inter-project meetings. Finally, process maps and lessons-learnt databases are examples of knowledge codification on the level of the PBO. These latter two types of organizational learning rely significantly less on organizational membership and more on organizational structures.

In a third study, Tim Brady and Andy Davies (2004), who not unlike Prencipe and Tell adopt a more processual approach, researched the capability development in two PBOs in the telecommunication industry by means not only of project-led learning, but also of project-to-project learning and project-to-organization learning. In the latter two cases of learning, the organization either supports the capability development process (project-toproject learning) or even results in developing project-based capabilities (project-toorganization learning). Once developed, the latter capabilities, reflected in a broad array of routines and practices in the two PBOs, allow the bottom-up learning from the project to the organization to be complemented by learning processes initiated top-down, i.e. from the permanent to the temporary system. Thus, this study, not unlike the one by Prencipe and Tell, not only considers the interplay between structure and agency, but also adopts a multi-level approach to understanding the role of the permanent in coordinating the temporary in PBOs. 
In a fourth study, Söderlund and Tell (2009) add a nuance to the development of organizational capabilities for managing projects by analysing the role of vanguard projects. In a longitudinal study of Asea/ABB's (1950-2000) power system division, heavily involved in the delivery of CoPS with a high degree of user involvement, the authors show how the long history of managing business projects (in the course of which the authors speak of 'project epochs') contributes to the refinement of the PBO and its project management capabilities over time. For their study, they adopt an explicit two-level approach, focusing on vanguard projects as well as the organization of ABB. The first epoch was dominated by the firm's close collaboration with Vattenfall as the main customer. These projects were so important for ABB that they 'were placed centrally in the organizational structure, [so that] they normally received extensive attention from general management' (Söderlund and Tell, 2009: 105). The second epoch was characterized by increasing internationalization, for which ABB had to develop 'its own capabilities to offer full-scale systems and project management' (p. 106). The third epoch saw an increasing focus on turnkey projects, combined with a further broadening and deepening of project management capabilities. These capabilities were embedded into ABB's then popular 'global matrix organization', which allowed the transfer of managing complex turnkey projects to other business units. Finally, the fourth epoch 'revolves around the increased responsibility for total solutions and even more advanced financial engineering' (p. 105). In this last epoch investigated, ABB added further project management capabilities to the organization by offering and delivering "total solutions": from feasibility studies and engineering to total project management and financing' (p. 107). Notwithstanding the partial overlap of these four project epochs, the market- and technology-related and organizational complexity increased over time and was reflected not only in respective changes of the formal structure of ABB but also in a varying focus on generating, organizing (including teamwork) and leading projects.

More recently, paying particular attention to tensions between the temporary and the permanent, Iben Stjerne and Silviya Svejenova (2016) used processual concepts like boundary work and institutionalization in their study of sequential filmmaking projects from the perspective of a PBO, a Danish film production firm. Based on their ethnography, the authors highlight not only the balancing act between the persistence of the organization as the permanent social system and the innovation focus of its temporary counterparts in this $\mathrm{PBO}$, but also the importance of boundary roles and respective boundary work to connect temporary and permanent organizing and manage the tensions between them. In addition, Stjerne and Svejenova emphasize the role of the institutional field in which the organization as well as its temporary spin-offs are embedded (see also Cattani et al., 2011). For more often than not, the field provides important resources and practices for managing tensions arising between the temporary and the permanent.

\section{Temporary organizing in inter-organizational (project) networks}

Just like organizations, inter-organizational networks with their more than temporary structures support the coordination of inter-organizational projects. Inter-organizational projects are temporary systems in which two or more organizations collaborate on a temporary basis, i.e. with an ex-ante agreed termination (Jones and Lichtenstein, 2008; 
Sydow and Braun, 2018). While the ex-ante agreed end of the collaboration may deviate significantly from the project's actual duration (as well-known examples demonstrate, from the Sydney Opera to the new Berlin Airport BER), it is the intentional temporariness that matters most for individuals working in a project, for the success and failure of a project and thereby of an organization, as well as for society as a whole; no matter whether the duration of the project is measured in hours or days, as in the case of content production for television or, as is often the case in the construction industry, in months and years.

Not only in classic project-based industries such as the construction industry, but also in most science-based fields (such as biotech, photonics or those involving smart materials) and creative industries (such as advertising or filmmaking), inter-organizational projects are a particularly common form of temporary organizing. More often than not, PNWs develop around PBOs like ABB and the inter-organizational CoPS projects they typically engage in (Söderlund and Tell, 2009). What is more, PNWs are significantly influenced by PBOs, which typically initiate and orchestrate them. Interestingly, in all of these industries or fields, organizations (and, more often than not, also individuals) tend to work together repeatedly, creating networks of more or less enduring relationships. These relationships allow not only for the exchange of complex knowledge and the development of mutual reciprocity, but, if reproduced, turn inter-organizational projects in these industries into (inter-organizational) project networks or PNWs (Lundin et al., 2015: 65-77; Manning, 2017; Oliveira and Lumineau, 2018; Windeler and Sydow, 2001).

Project networks are, in sharp contrast to the particular inter-organizational projects coordinated in them, more than temporary systems, because they reflect the recurrent collaboration between all (or a significant number of) project members (DeFillippi and Sydow, 2016; Windeler and Sydow, 2001). In their study of content production for German television, Windeler and Sydow (2001) show that a project network emerged as a response to major shifts in the industry caused by privatization, globalization and digitalization. Former in-house production by broadcasters was organized increasingly in inter-organizational projects, in which broadcasters continued to be involved as active, value co-creating customers and, together with independent production firms, to coordinate the production process of directors, camera operators, studios, cutters and other service providers. The authors explicitly analyse the co-constitution of this organizational form of collaborative content production on the one hand and the changes in the German television industry on the other as being a structuration process. They show that project members of a particular content producer are enabled to produce content in the time given by actualizing and re-specifying practices established in former projects by this producer, thereby institutionalizing them as practices of the project network or even of the field of TV production.

The structuration perspective taken by these authors puts the interplay of (inter-) organizational practices in project networks, enabled and constrained by organizational, network and industry/field practices, centre stage. The respective organizational, network and field structures, i.e. rules of signification and legitimation and resources of domination (Giddens, 1984), allow for the stability of project practices. This stability is, contradictory and dialectically as this may sound (Farjoun, 2010), a necessary precondition for 
the flexibility of this organizational form in an increasingly dynamic environment. One important insight this study provides is the continuing reproduction of the separation between the private and the public world of television production in Germany; whereby the latter continued and continues to be economically important, despite the impact of privatization, globalization and digitalization on the development of the industry. Concluding their study, Windeler and Sydow (2001: 1055) state:

The analysis showed that the evolution and, finally, institutionalisation of industry practices does not mean the forced adaptation of externally given practices. The institutionalisation is seen more as a multi-level, multi-dimensional and multi-actor endogenous development, one in which different knowledgeable agents recursively and powerfully refer to industry practices, and their underlying sets of rules and resources, in their network practices. In doing so, they reproduce or change industry structures on the three institutional dimensions of signification, domination, and legitimation. The development of industry and network processes should thus be understood not only as a co-evolutionary process but as a co-evolutionary multi-level constitution process.

Beth A Bechky (2006) also investigates film production from a structurationist perspective. She makes the strong point that the stability required by temporary organizations to be efficient and effective does not rely alone on recurrent collaboration with the same individuals (or organizations), offering inter-organizational career opportunities. Rather, the project itself as a temporary organization is characterized by a more or less enduring 'structured role system', the nuances of which are negotiated in situ, but develop across projects. The respective role structures not only ease project coordination, but also enable the swift development of trust among the project participants who, at least to some extent, stem from different organizations.

In a third study, Stephan Manning (2010) also used structuration theory and analysed data on the emergent project network of a European education researcher, aiming to investigate which practices he developed over a series of 10 projects with a total of 59 other researchers. With the help of an institutional analysis, combined with an analysis of strategic contact, this author found that, over time, the focal researcher formed long-term relationships with an increasing number of researchers from different organizations reflecting the basic idea of PNWs. The institutional analysis revealed important properties of the field and its organizations, as well as of the funding programmes and regulations and of the professionalization of project management which, to some extent at least, changed over the period investigated. The analysis of strategic conduct revealed several practices that helped the focal researcher to form and develop his project networks over the whole period under scrutiny. Among them were practices of making and renewing project-based contacts, pooling potential project partners, and maintaining core project partnerships. These practices helped not only to develop, but also to stabilize the PNWs of this particular actor and also his central network position. The fact that his PNWs continued to experience some turnover of project participants is also characteristic of this more than temporary form of organization.

In a fourth study, Stephan Manning and Jörg Sydow (2011) investigated the production of movies for television. Based on a network analysis and ethnographic work at two film sets, they identified two main sources of stability for this form of temporary organizing. 
First, a core group of actors who, at least to a significant degree, repeatedly collaborated in different movie projects. Second, project practices (e.g. connecting with former team members as well as tasks) were used in order to reproduce what the authors call a 'collaborative path', i.e. 'sequences of projects that allow partners to exploit established, but also explore new resources and capabilities, while actively bridging periods of latency' (Manning and Sydow, 2011: 1369). Also adopting a structuration perspective, this study captures the dynamic interplay between the temporary and the permanent in the project network rather than on the project level of analysis. Not unlike the study by Windeler and Sydow (2001), it also focuses on the role of organizational rules and resources in the constitution of the inter-organizational project network.

In a more recent study, Freek van Berkel et al. (2016) use a mixed-method approach and investigate how time pressure affects the coordination between mostly fast-paced temporary and typically slower-paced organizations in large public infrastructure projects. The study not only highlights the importance (to be expected) of different time orientations and the political context for the difficulties in coordinating this kind of interorganizational project. Rather, the study also unearths the role of the organizations in providing transactive memories for setting up and maintaining timely coordination, but - as becomes very prominent in the study - for hindering it too. However, in contrast to the other studies, this one remains silent not only about the process or practice theory adopted, but also about the role of the field in which the projects, the organizations and, hence, the project network is embedded.

\section{Discussion and conclusion: Preliminary generalizations}

The studies of the PBOs and PNWs reviewed demonstrate that several structure- and agency-related properties have been considered, mostly on more than one level of analysis. Most of these studies adopted an explicit process framework, while several of them even made use of practice theory in general or structuration theory in particular. The studies have therefore contributed significantly to the clarification of how the enactment of permanent structures contributes to the stability of these temporary, more flexible forms of organizing (see Table 1 for a summary). Towards this end, the studies reviewed show a tendency to include not simply more levels of analysis as such, but more macro levels. In particular, they seem to account increasingly for the institutional embeddedness of PBOs and PNWs in organizational fields. Society at large, however, both in these studies and quite typically also for research on temporary organizing and project management, does not figure prominently in these studies of the interplay of the temporary and the permanent and the dialectics of stability and change. Even the research by Windeler and Sydow (2001) only includes society-wide (or even transnational professional) norms as a background consideration when it looks at changes in industrial structures following changes in federal laws.

Applying social theory in general and practice-based theories such as structuration theory in particular is new neither for research on management and organizations in general (e.g. Barley and Tolbert, 1997; Jarzabkowski, 2008; Ortmann et al., 1990, 1997; Whittington, 1992), nor for research on temporary organizing in particular (e.g. Floricel et al., 2014; Manning, 2010; Windeler and Sydow, 2001). Nevertheless, so far only a 
Table I. Sources of permanency/stability in project-based organizing.

\begin{tabular}{lll}
\hline Author(s) / Main focus & Structure & Agency \\
level(s) & & \\
\hline
\end{tabular}

\section{Studies of PBOs}

Hobday (2000)

organization, embedded

in a field

Prencipe and Tell

(200I)

individual, group/project

and organization

Brady and Davies

(2004)

project, organization

Söderlund and Tell

(2009)

project, organization

Stjerne and Svejenova

(2016)

project, organization,

field

\section{Studies of PNWs}

Windeler and Sydow

(200I)

project, network, field

Bechky (2006)

project, network

Manning (2010)

project, organization,

network, field

Manning and Sydow

(20II)

project, network, field

van Berkel et al. (20l6)

project, organization,

network
Structures of the organization

that, for instance, are

routine-enhancing and allow

project-tracking

An organization's learning landscape

Emerging bottom-up learning, complemented by designed top-down learning

$A B B$ as 'p-form', in which projects with the most important customer were originally centrally placed, to later integration of project portfolios via a 'global matrix organization'

Boundary roles, 'distance' of the temporary to the permanent

Interplay of sets of rules of signification and legitimation and resources of domination on organizational, network and industry levels

Structured role system

Structure of a personal/ professional project network of a European researcher

Repeated collaboration of core teams with collective structures

Recurrent time pressure, amplified by the political context; different paces of temporary and permanent
Project-centric agency, solving the problem and task at hand, even at the expense of keeping the broader picture in mind Accumulating experience, articulating and codifying knowledge, in particular for learning across projects Enactment of project-related routines and practices

From generating vanguard projects to developing broader project capabilities for managing turnkey projects and providing 'total solutions' to global customers

Boundary work and balancing acts to resolve tensions, strategically connecting the past, present and future

Project agency constituted by knowledgeable agents within and between projects

Role enactment via thanking, admonishing and joking Practices of making and renewing project-based contacts, pooling potential project partners, and maintaining core project partnerships, enacted and carried out by 'project entrepreneurs' Local search for team members, connecting practices in order to enact team and task similarities between past, present, and potential future projects Coordination practices 
little research using such theories has been devoted directly to a better understanding of the interface between the temporary and the permanent. This is problematic in view of the rapid spread, not only of project-based forms of organizing, but also of platform organizations (McIntyre and Srinivasan, 2017) or other forms of network and partial organizations (Ahrne and Brunsson, 2018). For all these forms seem to rely increasingly on temporary structures but, seemingly paradoxically, at the same time heavily on more permanent structures.

Temporary organizing, even in rather stable settings like organizations and/or interorganizational networks, does indeed challenge forms of permanent organizing as in Weber's concept of the bureaucratic organization. However, as has been argued, such more permanent forms continue in fact to play an important role, not least for temporary organizing, as they help to manage the duality of stability and change (Farjoun, 2010). In times of an increasing number, speed and scope of societal changes towards more temporary organizations, one could even argue that temporary organizing contributes essentially to the survival of more permanent social systems like organizations and inter-organizational networks. Thereby and without doubt, the basic characteristics of such systems will change - at least if compared to Weber's understanding of organizations. In addition, it is important to note that these very organizations are the major driver of forms of temporary organizing - and likely to continue to be so, whether as PBOs, lead organizations in PNWs or platform operators. While the studies we have discussed show that the interaction of the temporary and the permanent is constitutive for temporary organizing in PBOs and PNWs, relevant questions remain open for future research. One important question is how actors (individuals or organizations) recursively mediate the temporary and the permanent in their social practices in and across the respective contexts. To answer this question, studies will need to clarify in significantly greater detail which actors act how together, or how actors monitor the temporary system from the outside; how, for instance, they signify the interplay of the temporary and the permanent for particular actions/events and make results achievable by combining the rules and resources of different relevant contexts. In addition, scholars need to determine which forms of interaction actors (consensually or controversially) consider legitimate in these contexts. Finally, researchers have to find out (on each of the relevant levels, and across them) which resources - such as knowledge, money or technologies - actors recursively use or qualify as being appropriate, for example, to bring about a productive interplay of the temporary with the permanent. Practice-based theories in general, and structuration theory with its moderate, multi-level approach in particular, should prove to be useful in such endeavours. This will presumably also be true for studying forms of temporary organizing other than PBOs and PNWs.

Beyond the questions outlined, there are three pressing issues for future research. A first issue concerns the influence that digital technologies and platform organizations have on the design and dissemination of temporary forms of organizing and more permanent structures. For both, digitalization and platform organization, open up new possibilities for organizing social activities and relationships. A second issue concerns the importance of temporary organizations for nation states, for instance with regard to institutions for the regulation of labour, taxes and social services when private regulations are supposed to supplement state regulations. A third pressing issue concerns the skills actors need in order to act competently in these new forms of temporary organizing embedded 
into more permanent structures, and what consequences this has for social inequality within and beyond individual nation states.

From the practice-based perspective outlined in this article, the societal change towards more fluid societies, diagnosed by Zygmund Bauman (2007) and others, is mainly the medium and result of organizations that - as collective actors - strategically draw upon forms of temporary organizing. Their respective activities and the chances of success are shaped in turn by the societal conditions given, enacted and, to some extent, co-produced in time and space. Organizations are therefore not likely to lose influence or even disappear due to the spread of temporary organizing, but will continue to change their forms, thus remaining powerful, and continue to shape social life. Since organizations will persevere as major societal actors, they will recursively implement a complex interplay of temporariness and permanence in society and remain crucial for a better understanding of the contexts of organizing and of sociation.

\section{Funding}

The authors received no financial support for the research, authorship, and/or publication of this article.

\section{ORCID iD}

Arnold Windeler (iD https://orcid.org/0000-0001-5243-8248

\section{Notes}

1. Anthony Giddens adopts this particular understanding of rules from Ludwig Wittgenstein (1988 [1953]: 344), who originally developed the idea that 'rule following' means mastering a particular technique, and that actors, most of the time at least, act on the basis of practical knowledge that allows them to know 'how to go on', even if they are not able to explain why they (have to) do so discursively. Giddens even generalizes this idea with an implicit reference to Alfred Schütz when he writes, 'actors employ typified schemes (formulae) in the course of their daily activities to negotiate routinely the situations of social life. Knowledge of procedure, or mastery of the techniques of "doing" social activity, is by definition methodological. That is to say, such knowledge does not specify all the situations which an actor might meet with, nor could do so; rather, it provides for the generalized capacity to respond to and influence an indeterminate range of social circumstances' (Giddens 1984: 22).

2. One important aspect in this discussion concerns the reflexivity involved in this understanding of social constitution. The idea of a reflexive constitution of the social paves the way not only for a sophisticated concept of the individual actor but also of the organization and, accordingly, the process of organizing. An organization is a rather specific social system, as it is 'a collectivity of some size, which has a high degree of reflexive coordination of the conditions of system reproduction' (Giddens 1990: 302), whose members as knowledgeable agents continuously produce and reproduce it in time and space, not least by ways of organizing, including temporary organizing.

\section{References}

Ahrne G and Brunsson N (2018) Organization Unbound. Cambridge: Cambridge University Press. Bakker RM (2010) Taking stock of temporary organizational forms: A systematic review and research agenda. International Journal of Management Reviews 12: 466-486. 
Bakker RM, DeFillippi RJ, Schwab A et al. (2016) Temporary organizing: Promises, processes, problems. Organization Studies 37: 1703-1719.

Barley SR and Tolbert PS (1997) Institutionalization and structuration: Studying the links between action and institution. Organization Studies 18: 93-117.

Bauman Z (2007) Liquid Times: Living in an Age of Uncertainty. Cambridge: Polity.

Bechky BA (2006) Gaffers, gofers, and grips: Role-based coordination in temporary organizations. Organization Science 17: 3-21.

Blau PM and Scott WR (2003 [1962]) Formal Organizations. A Comparative Approach. Stanford, CA: Stanford University Press.

Brady T and Davies A (2004) Building project capabilities: From exploratory to exploitative learning. Organization Studies 25: 1601-1621.

Cattani G, Ferriani S, Frederiksen L et al. (2011) Project-based Organizing and Strategic Management: A Long-term Research Agenda on Temporary Organizational Forms. Bingley: Emerald.

DeFillippi RJ and Arthur MB (1998) Paradox in project-based enterprise: The case of film making. California Management Review 40: 125-139.

DeFillippi RJ and Sydow J (2016) Project networks - Governance choices and paradoxical tensions. Project Management Journal 47: 6-17.

Eccles RG (1981) The quasi-firm in the construction industry. Journal of Economic Behavior and Organization 2: 335-357.

Ekstedt E, Lundin RA, Söderholm A et al. (1999) Neo-industrial Organizing: Renewal by Action and Knowledge Formation in a Project-intensive Economy. London: Routledge.

Emirbayer M and Mische A (1998) What is agency? American Journal of Sociology 103: 962-1023.

Engwall M (2003) No project is an island: Linking projects to history and context. Research Policy 32: 789-808.

Farjoun M (2010) Beyond dualism: Stability and change as a duality. Academy of Management Review 35: 202-225.

Floricel S, Bonneau C, Aubry M et al. (2014) Extending project management research: Insights from social theories. International Journal of Project Management 32: 1091-1107.

Giddens A (1984) The Constitution of Society: Outline of the Theory of Structuration. Cambridge: Polity Press.

Giddens A (1990) Structuration theory and sociological analysis. In: Clark J, Modgil C and Modgil S (eds) Anthony Giddens: Consensus and Controversy. London: Falmer, pp. 297-315.

Goodman RA and Goodman LP (1976) Some management issues in temporary systems: A study of professional development and manpower - The theater case. Administrative Science Quarterly 21: 494-500.

Grabher G (2004) Temporary architectures of learning: Knowledge governance in project ecologies. Organization Studies 25: 1491-1514.

Helin J, Hernes T, Hjorth D et al. (2014) The Oxford Handbook of Process Philosophy and Organization Studies. Oxford: Oxford University Press.

Hobday M (2000) The project-based organisation: An ideal form for managing complex products and systems? Research Policy 29: 871-893.

Hond F de, Boersmaa FK, Heresa L et al. (2012) Giddens à la carte? Appraising empirical applications of Structuration Theory in management and organization studies. Journal of Political Power 5: 239-264.

Jacobsson M, Burström T and Wilson TL (2013) The role of transition in temporary organizations: Linking temporary to the permanent. International Journal of Managing Projects in Business 6: 576-586. 
Jarzabkowski P (2008) Shaping strategy as a structuration process. Academy of Management Journal 51: 621-650.

Jones C and Lichtenstein BB (2008) Temporary inter-organizational projects: How temporal and social embeddedness enhance coordination and manage uncertainty. In: Cropper S, Huxham $\mathrm{C}$, Ebers $\mathrm{M}$ et al. (eds) The Oxford Handbook of Inter-organizational Relations. Oxford: Oxford University Press, pp. 231-255.

Langley A, Smallman C, Tsoukas H et al. (2013) Process studies of change in organization and management: Unveiling temporality, activity, and flow. Academy of Management Journal 56: $1-13$.

Lundin RA and Söderholm A (1995) A theory of the temporary organization. Scandinavian Journal of Management 11: 437-455.

Lundin RA, Arvidsson N, Brady T et al. (2015) Managing and Working in Project Society: Institutional Challenges of Temporary Organizations. Cambridge: Cambridge University Press.

McIntyre DP and Srinivasan A (2017) Networks, platforms, and strategy: Emerging views and next steps. Strategic Management Journal 38: 141-160.

Manning S (2010) The strategic formation of project networks: A relational practice perspective. Human Relations 63: 551-574.

Manning S (2017) The rise of project network organizations: Building core teams and flexible partner pools for interorganizational projects. Research Policy 46: 1399-1415.

Manning S and Sydow J (2011) Projects, paths, practices: Sustaining and leveraging project-based relationships. Industrial and Corporate Change 20: 1369-1402.

Oliveira N and Lumineau F (2018) How coordination trajectories influence the performance of interorganizational project networks. Organization Science 28(6).

Ortmann G, Sydow J and Windeler A (1997) Organisation als reflexive Strukturation. In: Ortmann G, Sydow J and Türk K (eds) Theorien der Organisation. Opladen: Westdeutscher Verlag, pp. 315-354.

Ortmann G, Windeler A, Becker A et al. (1990) Computer und Macht in Organisationen. Mikropolitische Analysen, Opladen: Westdeutscher Verlag.

Packendorff J (1995) Inquiring into the temporary organization: New directions for project management research. Scandinavian Journal of Management 11: 319-333.

Perrow C (1991) A society of organizations. Theory and Society 20: 725-762.

Powell WW, Koput KW and Smith-Doerr L (1996) Interorganizational collaboration and the locus of innovation: Networks of learning in biotechnology. Administrative Science Quarterly 41: $116-145$.

Pozzebon M (2004) The influence of a structurationist view on strategic management research. Journal of Management Studies 41: 247-272.

Pozzebon M (2013) Structuration theory. In: Kessler EH (ed.) Encyclopedia of Management Theory. Thousand Oaks, CA: Sage, pp. 806-809.

Prencipe A and Tell F (2001) Inter-project learning: Processes and outcome of knowledge codification in project-based firms. Research Policy 30: 1373-1394.

Sahlin-Andersson K and Söderholm A (2002) Beyond Project Management: New Perspectives on the Temporary-Permanent Dilemma. Malmö: Liber Ekonomi.

Seidl D and Whittington R (2014) Enlarging the strategy-as-practice research agenda: Towards taller and flatter ontologies. Organization Studies 35: 1407-1421.

Söderlund J and Tell F (2009) The P-form organization and the dynamics of project competence: Project epochs in Asea/ABB, 1950-2000. International Journal of Project Management 27: 101-112.

Stjerne IS and Svejenova S (2016) Connecting temporary and permanent organizing: Tensions and boundary work in sequential film projects. Organization Studies 37: 1771-1792. 
Sydow J and Braun T (2018) Projects as temporary organizations: An agenda for further theorizing the interorganizational dimension. International Journal of Project Management 36: 4-11.

Sydow J and Windeler A (1998) Organizing and evaluating interfirm networks: A structurationist perspective on network processes and effectiveness. Organization Science 9: 265-284.

van Berkel FJFW, Ferguson JE and Groenewegen P (2016) Speedy delivery versus long-term objectives: How time pressure affects coordination between temporary projects and permanent organizations. Long Range Planning 49: 661-673.

Weber M (1968 [1922]) Economy and Society: An Outline of Interpretive Sociology. New York: Bedminster Press.

Weick KE (2009) Organized impermanence: An overview. In: Weick KE (ed.) Making Sense of the Organization: The Impermanent Organization. Chichester: Wiley, pp. 3-8.

Weick KE, Sutcliffe KM and Obstfeld D (2005) Organizing and the process of sensemaking. Organization Science 16: 409-421.

Whittington R (1992) Putting Giddens into action: Social systems and managerial agency. Journal of Management Studies 29: 693-712.

Whittington R (2010) Giddens, structuration theory and strategy as practice. In: Golsorkhi D, Rouleau L, Seidl D et al. (eds) Cambridge Handbook of Strategy as Practice. Cambridge: Cambridge University Press, pp. 145-164.

Windeler A (2001) Unternehmungsnetzwerke. Konstitution und Strukturation. Wiesbaden: Westdeutscher Verlag.

Windeler A (2006) Structuration theory. In: Beckert J and Zafirovski M (eds) International Encyclopedia of Economic Sociology. Abingdon: Routledge, pp. 654-658.

Windeler A (2018) Reflexive innovation: On innovation in radicalized modernity. In: Rammert W, Windeler A, Knoblauch H et al. (eds) Innovation Society Today: Perspectives, Fields and Cases. Wiesbaden: Springer VS, pp. 65-105.

Windeler A and Sydow J (2001) Project networks and changing industry practices: Collaborative content production in the German television industry. Organization Studies 22: 1035-1061.

Wittgenstein L (1988 [1953]) Philosophische Untersuchungen. Frankfurt am Main: Suhrkamp.

\section{Author biographies}

Jörg Sydow is a Professor of Management at the School of Business and Economics of Freie Universität Berlin. He is or was a member of the editorial boards of Organization Studies, Organization Science, Academy of Management Journal, Academy of Management Review, Journal of Management Studies and The Scandinavian Journal of Management. Currently he is a Senior Editor of Organization Studies. Recently he co-edited Managing Inter-organizational Collaborations - Process Views (Emerald, 2019).

Arnold Windeler is Professor of Sociology and speaker of the Research Training Group 'Innovations Society Today: The Reflexive Creation of Novelty' at Technische Universität Berlin, Germany. His areas of specialization and research are social theory, theory of organization, interfirm networks and innovation. He was visiting scholar at Harvard University, Stanford University, and University of California, Berkeley in the US. In addition, he has taught recurrently at University of Lucerne, Switzerland.

\section{Résumé}

L'organisation temporaire en général et l'organisation par projet en particulier ne doivent être comprises que par rapport à des contextes plus permanents tels que les organisations, les réseaux inter-organisationnels, les industries / domaines et la société. Compte tenu de la capacité des organisations à concilier permanence et temporalité, il est 
peu probable qu'elles disparaissent en raison de l'organisation temporaire. Au contraire, elles continueront de changer de forme de façon récurrente et, de ce fait, resteront aujourd'hui un élément essentiel de nos sociétés plus fluides. En utilisant une perspective basée sur la pratique informée par la théorie de la structuration et en examinant de manière critique les études empiriques des organisations basées sur des projets et des réseaux de projets inter-organisationnels, nous fournissons une compréhension plus profonde de l'interaction complexe entre le temporaire et le permanent.

\section{Mots-clés}

Anthony Giddens, bureaucraties, organisation temporaire, organisations, organisations basées sur la pratique, réseaux de projets, théorie de la pratique

\section{Resumen}

La organización temporal en general y la organización basada en proyectos en particular deben entenderse en relación con contextos más permanentes como las organizaciones, las redes interorganizativas, las industrias/campos y la sociedad. Ante la capacidad de las organizaciones para equilibrar permanencia y temporalidad, no parece probable que estas desaparezcan debido a la organización temporal. Más bien seguirán cambiando recurrentemente su forma $y$, de ese modo, seguirán siendo un elemento esencial de las sociedades fluidas actuales. Empleando una perspectiva basada en la práctica, en la teoría de la estructuración y en la revisión crítica de los estudios empíricos sobre organizaciones basadas en proyectos y redes de proyectos interorganizacionales, proponemos una comprensión más profunda de la compleja interacción entre lo temporal y lo permanente.

\section{Palabras clave}

Anthony Giddens, burocracias, organización temporal, organizaciones, organizaciones basadas en la práctica, redes de proyectos, teoría ligada a la práctica 